Економічні науки: збірник наукових праць Луцького національного технічного університету. Серія "Регіональна економіка". Випуск 18 (71). Редкол.: відп. ред. д.е.н., професор Л.Л. Ковальська. Луцьк: ІВВ Луцького НТУ, 2021. 278 с.

relationships: empirical evidence from regional networks. European Journal of Information Systems. 2021. DOI: 10.1080/0960085X.2020.1869914.

12. Panda S. Strategic IT-business alignment capability and organizational performance: roles of organizational agility and environmental factors. Journal of Asia Business Studies. 2021. Vol. ahead-of-print. https://doi.org/10.1108/JABS-092020-0371.

13. Keijser Ch., Belderbos R., Goedhuys M. Governance and learning in global, regional, and local value chains: The IT enabled services industry in South Africa. World Development. 2021. Volume 141. 105398. https://doi.org/10.1016/j.worlddev.2021.105398.

14. Alsop T. Yearly growth forecast IT spending worldwide 2016-2022 / 2021 Statista. URL: https://www.statista.com/statistics/268940/percent-growth-in-itspending-worldwide-by-segment/ (дата звернення: 10.09.2021).

15. Middle East ICT Market Outlook, 2021 - Innovative Business Models Spur Growth / 2021 Research and Markets. URL: https://www.researchandmarkets.com/reports/5333041/middle-east-ict-marketoutlook-2021-innovative (дата звернення: 10.09.2021).

16. Gartner Forecasts Worldwide IT Spending to Grow 9\% in 2021. Technology Spending Enters a New Build Budget Phase. STAMFORD, Conn., July 14, 2021. Press Release / 2021 Gartner, Inc. URL: https://www.gartner.com/en/newsroom/press-releases/2021-07-14-gartner-forecastsworldwide-it-spending-to-grow-9-percent-2021 (дата звернення: 10.09.2021).

17. Alhorr H. S., Boal K., Cowden B. J. Regional economic integration and international strategic alliances: evidence from the EU. Multinational Business Review, 2012. Vol. 20. № 1. P. 44-66.

DOI: https://doi.org/10.36910/2707-6296-2021-18(71)-11

УДК 331.109

Куцай Н.С., к.е.н., доцент

Луцький національний технічний університет

\title{
УПРАВЛІННЯ КОНФЛІКТАМИ НА ПІДПРИЄМСТВІ
}

У статті розглянуто основні причини та особливості впливу конфлікту в трудовому колективі на підприємстві, визначено елементи конфліктних ситуацій, проведено характеристику факторів, які впливають на рівень конфліктних ситуацій на підприємстві та розглянуто причини їх виникнення. Запропоновано кроки для ефективного управління вирішення конфліктів на підприємстві. 
Економічні науки: збірник наукових праць Луцького національного технічного університету. Серія "Регіональна економіка". Випуск 18 (71). Редкол.: відп. ред. д.е.н., професор Л.Л. Ковальська. Луиьк: ІВВ Луиького НТУ, 2021. 278 с.

Ключові слова: конфлікт, управління конфліктами, конфлікти на підприємстві, конфліктні ситуації, особливості управління конфліктами на підприємстві.

\section{Kutsai N.}

\section{CONFLICT MANAGEMENT AT THE ENTERPRISE}

The article considers the main causes and features of the impact of conflict in the workforce at the enterprise, identifies elements of conflict situations, describes the factors that affect the level of conflict situations at the enterprise and considers the causes of their occurrence. Steps for effective management of conflict resolution in the enterprise are offered.

Conflict is an integral aspect of the lives of people and organizations that occur $i$ almost any enterprise. Conflicts arise in enterprises as a result of competition for an advantage that does not correspond to the style of leadership, the lack of common resources. They exist both in large holdings and in small enterprises. Conflict-free enterprises are very rare, so timely detection and resolution plays a very important role in enterprise management.

Using world practices in enterprise development, it is important to remember that introducing them on the Ukrainian market, a variety of conflict situations can arise. Therefore, it is very important to find out the main causes and features of the impact of conflict in the workforce at the company, identify the main elements of conflict situations, characterize the factors that affect the level of conflict situations at the company and consider the causes of various conflicts in the company.

The concept of the word "conflict" is colored in shades of negativity such as: aggression, argument, clarification of attitude, quarrel, anger, rage and threats. As a result, it is thought that conflict is always an undesirable phenomenon that should always be avoided. As for even the emergence of controversial situations. But every conflict has two sides: good and bad. The positive side of conflicts is that with its help you can get benefits and experience from the situation, identify the main problem and as a result of the dispute to find ways to resolve them. Depending on the situation, conflict can be useful.

Usually speaking of conflict, it can be noted that it is a competition to meet their needs, contradictions in views, ideas, goals, thoughts that arise in the interaction and collision of people, accompanied by negative emotions that go beyond generally accepted standards. Thus, a conflict is an exchange of energy, which requires at least two people who understand the conflict as a lack of agreement between people or entire teams in the enterprise.

Key words: conflict, conflict management, conflicts at the enterprise, conflict situations, features of conflict management at the enterprise.

\section{Куцай Н.С.}

\section{УПРАВЛЕНИЕ КОНФЛИКТАМИ НА ПРЕДПРИЯТИИ}

В статье рассмотрены основные причины и особенности влияния конфликта в трудовом коллективе на предприятии, определены элементы конфликтных ситуаций, проведена характеристика факторов, влияющих на уровень конфликтных ситуаций на 
Економічні науки: збірник наукових праць Луцького національного технічного університету. Серія "Регіональна економіка". Випуск 18 (71). Редкол.: відп. ред. д.е.н., професор Л.Л. Ковальська. Луиьк: ІВВ Луцьького НТУ, 2021. 278 с.

предприятии и рассмотрены причины их возникновения. Предложены шаги по эффективному управлению разрешения конфликтов на предприятии.

Ключевые слова: конфликт, управление конфликтами, конфликты на предприятии, конфликтные ситуации, особенности управления конфликтами на предприятии.

\section{Постановка проблеми у загальному вигляді і її зв'язок} 3 важливими науковими та практичними завданнями. Конфлікт це невіддільний аспект в житті людей і організації, які зустрічаються майже на будь-якому підприємстві. Конфлікти виникають на підприємствах в результаті конкуренції за перевагу, що не відповідає стилю керівництва, дефіциту загальних ресурсів. Вони існують як в великих холдингах, так i на малих підприємствах. Підприємства без конфліктів зустрічаються дуже рідко, тому своєчасне виявлення і дозвіл його відіграє дуже важливу роль в менеджменті підприємства.

Використовуючи світові практики в розвитку підприємства, важливо пам'ятати, що впроваджуючи їх на українському ринку, можуть виникнути найрізноманітніші конфліктні ситуації. Тому дуже важливо з'ясувати основні причини та особливості впливу конфлікту в трудовому колективі на підприємстві, визначити основні елементи конфліктних ситуацій, провести характеристику факторів, які впливають на рівень конфліктних ситуацій на підприємстві та розглянути причини їх виникнення, що допоможе зменшити появу різних конфліктів на підприємстві.

Аналіз останніх досліджень, у яких започатковано вирішення проблеми. Визначень сутності конфлікту дуже багато, i тому завдання дати точне визначення поняттю «конфлікт» виявилася нелегкою. Багато вітчизняних та зарубіжних учених в своїх наукових роботах зіставляли різні визначення конфлікту, до яких можна віднести Анцупова А.Я., Біловодську О.А., Краснову Н.П., Новікову Н., Сергієнко Т.I., Сочинську-Сибірцеву I.M. [1-6], і прийшли до висновку про відсутність сформованого загальновизнаного розуміння конфлікту. Разом з тим сучасна практика розвитку підприємства дає змогу усвідомити, що проблеми ефективного управління 
Економічні науки: збірник наукових праць Луцького національного технічного університету. Серія "Регіональна економіка". Випуск 18 (71). Редкол.: відп. ред. д.е.н., професор Л.Л. Ковальська. Луиьк: ІВВ Луиького НТУ, 2021. 278 с.

конфліктами на підприємстві набувають додаткової актуальності в мінливому середовищі.

Цілі статті. Мета дослідження полягає у виявленні основних причини та особливостей управління впливу конфлікту в трудовому колективі на підприємстві.

Виклад основного матеріалу дослідження 3 повним обгрунтуванням отриманих наукових результатів. Поняття, яке несе слово «конфлікт», забарвлене в відтінки негативу такі як: агресія, суперечка, з'ясування ставлення, сварка, лють, злість і загрози. В результаті з'являється думка, що конфлікт це завжди небажане явище, яке треба завжди уникати. Що стосується навіть появі спірних ситуацій. Але у кожного конфлікту є дві сторони: хороша і погана. Позитивною стороною в конфліктах $\epsilon$ те, що 3 його допомогою можна отримати користь і досвід із ситуації яка трапилася, визначити головну проблему i в результаті суперечки знайти способи їх вирішення. Залежно від ситуації конфлікт буває корисний.

Зазвичай кажучи про конфлікт, можна відзначити, що це конкуренція задоволення своїх потреб, протиріччя в поглядах, ідеях, цілях, думках, що виникають при взаємодії і зіткненні людей, супроводжуються негативними емоціями, які виходять за рамки загальноприйнятих стандартів.

Таким чином, конфлікт це обмін енергією, в якій потрібні мінімум дві людини, розуміють конфлікт як відсутність згоди між людьми, або цілими колективами на підприємстві.

В основі будь-якого конфлікту на підприємстві лежить протиріччя та непорозуміння. При конфлікті, можна виділити наступні три основні стадії його розвитку: 1) передконфліктна; 2) конфліктна; 3) післяконфліктна [7].

Передконфліктна стадія - це такий стан справ, інтересів, думок учасників конфлікту, які вступають в протиріччя, але відкритого зіткнення один 3 одним ще немає. Тут конфліктна ситуація не має чіткого початку i завершення. У багатьох випадках, така конфліктна ситуація виникає 3 великих суперечностей, але іноді буває, що конфлікт виник через дрібниці: різко сказаних слів, різниці у думках і т. д. Дати 
Економічні науки: збірник наукових праць Луцького національного технічного університету. Серія "Регіональна економіка". Випуск 18 (71). Редкол.: відп. ред. д.е.н., професор Л.Л. Ковальська. Луцьк: ІВВ Луцького НТУ, 2021. 278 с.

відповідь на питання, чому відбуваються конфлікти в повною мірою неможливо. Але кожній людині необхідно знати основні базові уявлення про природу конфлікту. Звичайно, це не означає, що людина, яка знає базові уявлення про природу конфлікту, не буде конфліктувати, швидше за навпаки він буде застосовувати своє знання, для того, щоб виходити 3 конфліктних ситуацій переможцем. Там, де $є$ конфлікт, $є$ і його елементи, які вказані на рисунку 1.

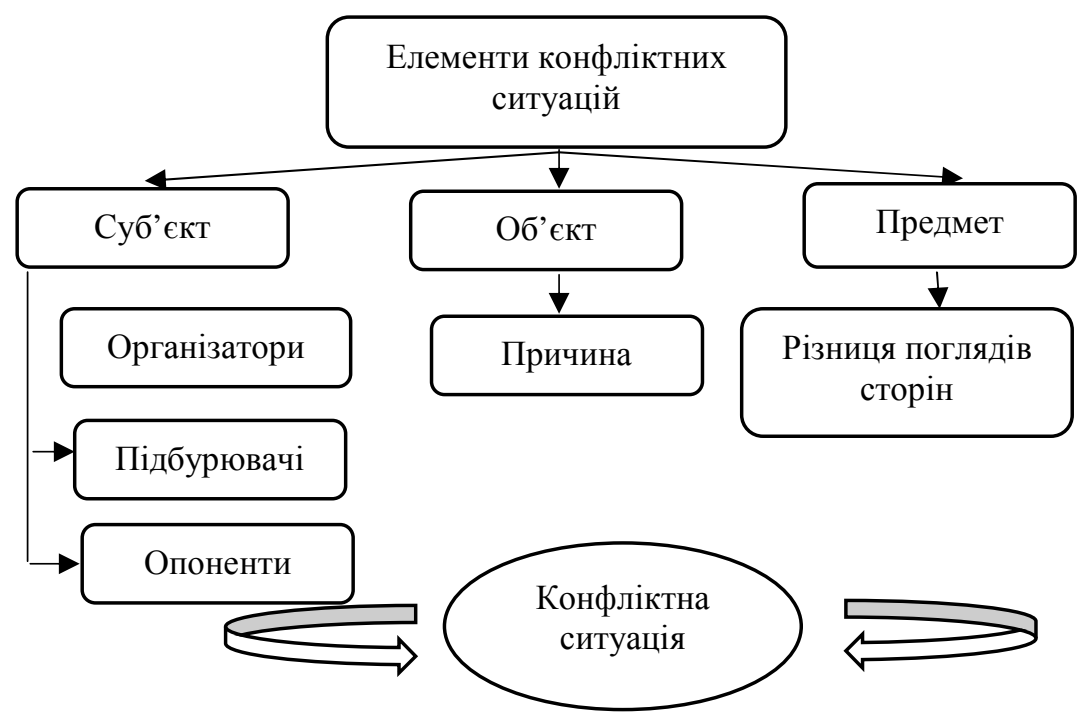

Рис. 1. Елементи конфліктних ситуацій на підприємстві Джерело: побудовано за [7]

Одним 3 головних елементів конфліктної ситуації $\epsilon$ суб'єкт (учасники конфлікту). Суб'єктом можуть бути опоненти, підбурювачі i організатори. Підбурювачі це особи, які підштовхують різні сторони до конфлікту, підливають масло у вогонь. Організатори - це ті особи, які тримаються на нейтральній стороні або можуть бути самостійною особою яка планує конфлікт, при цьому отримують вигоду при виникнення конфлікту. 
Економічні науки: збірник наукових праць Луцького національного технічного університету. Серія "Регіональна економіка". Випуск 18 (71). Редкол.: відп. ред. д.е.н., професор Л.Л. Ковальська. Луиьк: ІВВ Луиького НТУ, 2021. 278 с.

Іншим важливим елементом конфліктної ситуації є об'єкт, через який така ситуація виникає на підприємстві. Об'єктом зазвичай є дефіцитний ресурс. Якщо об'єкт перестає існувати, то і конфліктна ситуація зникне. Відмінність поглядів сторін на об'єкт (кожна прагне їм володіти) утворює предмет конфліктної ситуаціі.

Друга стадія конфлікту являє собою сам конфлікт. На цій стадії суперечка стає відкритою і яскраво виражається в різних видах конфліктної поведінки.

Третя стадія - післяконфліктна. Тут переглядаються результати спору та робляться висновки.

На підприємстві існує безліч причин конфліктів; проте конфлікти всередині людини зазвичай виникають, коли людина не впевнена в тому, яке завдання він повинен виконувати, якщо він не чітко визначений керівником або відповідальною особою.

Крім того, якщо завдання окремих осіб, які працюють в групі, чітко не визначені керівництвом, це призводить до більшої кількості конфліктів. Конфлікти можуть виникнути між окремими особами і групами, якщо цілі не вказані для окремих осіб усередині групи. Крім того, є й інші джерела конфліктів всередині підприємства, а саме: спільне використання ресурсів, особливо робочої сили, грошових матеріалів, обладнання та простору. Ресурсів дуже мало, людям завжди доводиться боротися за них, і кінцевий результат призведе до конфлікту. Взаємозалежність співробітників один від одного також може привести до конфлікту. Зазвичай це відбувається, коли два або більше завдання залежать один від одного для завершення роботи, особливо коли завдання проходить етапи в різних відділах, один відділ завершить роботу своєчасно, а інший відділ може затримати кінцеве виконання завдання. Керівництво може звинуватити всі підрозділи, які беруть участь в цьому процесі, що може привести до конфлікту.

Виділяють дві групи факторів конфліктів, що сприяють виникненню соціальної напруженості в трудовому колективі на підприємстві: внутрішні та зовнішні (табл. 1) [8]. 
Економічні науки: збірник наукових праць Луцького національного технічного університету. Серія "Регіональна економіка". Випуск 18 (71). Редкол.: відп. ред. д.е.н., професор Л.Л. Ковальська. Луиьк: ІВВ Луиького НТУ, 2021. 278 с.

Внутрішні конфлікти виникають на підприємстві i дозволяються, як правило, через існуючі нормативи і угоди, тобто так звані правила, прийняті на певному рівні і між зацікавленими сторонами.

Таблиця 1

Внутрішні та зовнішні фактори конфліктів на підприємстві

\begin{tabular}{|c|c|}
\hline Внутрішні фактори & Зовнішні фактори \\
\hline 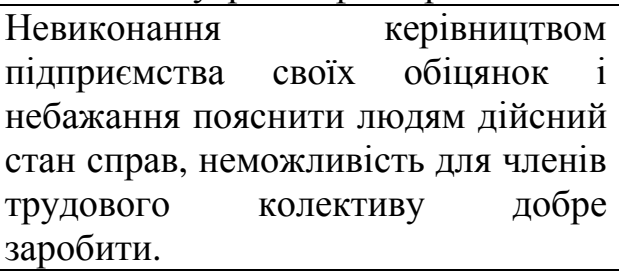 & $\begin{array}{lr}\text { Дестабілізація } & \text { стану в } \\
\text { країні, } & \text { зіткнення } \\
\text { iнтересів } & \text { різних } \\
\text { політичних груп. }\end{array}$ \\
\hline $\begin{array}{l}\text { Відсутність видимих результатів } \\
\text { предметної турботи про поліпшення } \\
\text { умов праці, побуту і відпочинку } \\
\text { працівників. }\end{array}$ & $\begin{array}{lr}\text { Виникнення } & \text { гострого } \\
\text { дефіциту на продукти i } \\
\text { товари } & \text { першої } \\
\text { необхідності. } & \\
\end{array}$ \\
\hline $\begin{array}{l}\text { Конфронтація персоналу управління } \\
\text { i працівників з-за несправедливого } \\
\text { розподілу матеріальних благ і } \\
\text { фонду оплати праці. }\end{array}$ & $\begin{array}{lr}\text { Обмеження } & \text { соціальних } \\
\text { пільг } & \text { в } \\
\text { законодавчих актах. }\end{array}$ \\
\hline $\begin{array}{llr}\text { Впровадження } & & \text { інноваційних } \\
\text { технологій } & \text { i } & \text { радикальних } \\
\text { перетворень } & \text { без } & \text { урахування } \\
\text { iнтересів працівників } & \\
\end{array}$ & $\begin{array}{lr}\text { Різке } & \text { ослаблення } \\
\text { правового } & \text { соціального } \\
\text { захисту інтересів членів } \\
\text { трудового колективу. }\end{array}$ \\
\hline $\begin{array}{l}\text { Підбурююча } \\
\text { неформальних лідерів. }\end{array}$ & $\begin{array}{l}\text { Забезпечення чесної i } \\
\text { сумлінної } \\
\text { незаконне } \\
\text { окремих грагачення } \\
\text { збродадн. }\end{array}$ \\
\hline
\end{tabular}

Конфлікти із зовнішнім середовищем - це конфлікти в більшості керівників і власників підприємств 3 конкурентами, клієнтами, постачальниками, з власною профспілкою.

Причин появи конфліктів на підприємстві дуже багато, в основному у кожного конфлікту буває по кілька причин. Головні причини наведені в таблиці 2. 
Економічні науки: збірник наукових праць Луцького національного технічного університету. Серія "Регіональна економіка". Випуск 18 (71). Редкол.: відп. ред. д.е.н., професор Л.Л. Ковальська. Луиьк: ІВВ Луцьккого НТУ, 2021. 278 с.

Таблиця 2

Причини конфліктів на підприємстві

\begin{tabular}{|c|c|}
\hline $\begin{array}{c}\text { Причини конфліктів } \\
\text { на підприємстві }\end{array}$ & Короткий опис конфлікту \\
\hline $\begin{array}{l}\text { Обмеженість } \\
\text { ресурсів і спосіб їх } \\
\text { розподілу } \\
\text { підприємстві }\end{array}$ & $\begin{array}{l}\text { Навіть у найбільших } \\
\text { ресурси піриємствах } \\
\text { Керівництво павжди } \\
\text { розподілити обмежені. } \\
\text { ресурси і матеріали, вирішити, як } \\
\text { групами, щоб найі } \\
\text { чином досягти цілей підприємства. }\end{array}$ \\
\hline $\begin{array}{l}\text { Взаємозв'язок } \\
\text { завдань } \\
\text { підприємстві }\end{array}$ & $\begin{array}{l}\text { Актуальною } \\
\text { в }\end{array}$ \\
\hline $\begin{array}{l}\text { Відмінності в } \\
\text { баченнях і цінностях }\end{array}$ & $\begin{array}{l}\text { Різні розуміння в цінностях, у } \\
\text { характері, меті, } \\
\text { людей часто є причиною конфлікту. }\end{array}$ \\
\hline $\begin{array}{l}\text { Різниця в цілях } \\
\text { різних підрозділів } \\
\end{array}$ & $\begin{array}{l}\text { Цілі одного підрозділу сходяться } 3 \\
\text { цілями іншого. }\end{array}$ \\
\hline $\begin{array}{l}\text { Неефективні } \\
\text { комунікації }\end{array}$ & $\begin{array}{l}\text { Складність передачі інформації, їі } \\
\text { недолік або несвоєчасне виконання } \\
\text { завдань при неефективній передачі } \\
\text { iнформації можуть привести до } \\
\text { конфліктів. }\end{array}$ \\
\hline
\end{tabular}

Профілактика та попередження конфліктів в першу чергу полягає в тому, щоб правильно організувати діяльність підприємства. Це завдання керівного складу та менеджерів 3 персоналу. необхідно вчасно відслідковувати невдоволення, появу неформальних лідерів, здатних негативно впливати на робочий процес. В основному присутні три різні стратегії розвитку конфліктів, використовувані на підприємстві:

1. Стимуляція конфліктів. Іноді, конфлікт потрібен для ефективної роботи підприємства. У таких випадках керівники навмисно стимулюють конфлікти. Наступні методи можуть 
Економічні науки: збірник наукових праць Луцького національного технічного університету. Серія "Регіональна економіка". Випуск 18 (71). Редкол.: відп. ред. д.е.н., професор Л.Л. Ковальська. Луиьк: ІВВ Луиького НТУ, 2021. 278 с.

використовуватися керівництвом для стимулювання конфлікту. Перебудова організації. Зміна структури на підприємстві $\epsilon$ ефективним методом стимулювання конфліктів.

2. Запобігання конфліктам. Для запобігання конфліктам можна використовувати такі стратегіі: Зменшення взаємозалежності. Потенціал конфлікту дуже великий, коли два або більше відділів взаємозалежні і спільно використовують ресурси. Отже, конфлікт може бути зведений до мінімуму, шляхом зменшення взаємозалежності між відділами. Ротація персоналу. Ротація співробітників між взаємозалежними відділами може поліпшити сприйняття і взаєморозуміння. співробітники можуть бачити загальну картину і обмінюватися думками один 3 одним. вони стають більш уважними i кооперативними. Створення взаємної довіри і спілкування.

3. Вирішення конфліктів або їх уникнення. У цьому методі робиться спроба об'єднати конфліктуючі сторони i поділитися загальними проблемами. акцент робиться на обмін інформацією, щоб уникнути непорозумінь і знайти області, що представляють спільний інтерес. Питання про те, хто правий або хто винен, уникає. Цей метод підходить для вирішення конфліктів, що виникають через непорозуміння.

Керівникам, менеджерам, лідерам на підприємстві потрібно робити певні кроки для ефективного управління вирішення конфліктних ситуацій на підприємстві:

1 крок. Визначити джерело конфлікту. Чим більше інформації про причини конфлікту, тим легше допомогти в його вирішенні.

2 крок. Подивитися за межі інциденту. Часто це не ситуація, а погляд на ситуацію, яка викликає гнів, і в кінцевому підсумку призводить до кричущої розбіжності або іншим видам і руйнівним ознакам конфлікту. Джерелом конфлікту може бути невелика проблема, яка виникла кілька місяців тому, але рівень стресу виріс до такої ступеня, що обидві сторони почали нападати один на одного, а не на вирішення реальної проблеми. 
Економічні науки: збірник наукових праць Луцького національного технічного університету. Серія "Регіональна економіка". Випуск 18 (71). Редкол.: відп. ред. д.е.н., професор Л.Л. Ковальська. Луиьк: ІВВ Луцьького НТУ, 2021. 278 с.

3 крок. Запит рішень. Після того, як кожна сторона побачить точку зору на конфлікт, наступним кроком буде з'ясувати, як можна змінити ситуацію.

4 крок. Визначити рішення, які можуть підтримати обидва учасники конфлікту. Висловити найбільш прийнятний курс дій. вказати гідності різних ідей не тільки з точки зору один одного, але і з точки зору переваг для підприємства.

5 крок. Угода. Посереднику потрібно, щоб обидві сторони потиснули один одному руки i погодилися на одну 3 альтернатив, визначених на кроці 4.

Висновки. Управління конфліктами на підприємстві являє собою процес впливу на персонал, необхідний для досягнення цілей, поставлених перед персоналом і підприємством в цілому. Конфлікт стає проблемою на підприємстві, коли виникають надмірні рівні стресу і непорозуміння. У всіх підприємствах існують конфлікти, протягом усього циклу його існування. Часткове пояснення цьому полягає в тому, що в структурі підприємства керівники зосереджують всі свої зусилля для того, щоб досягти мети. А загальна атмосфера на робочому місці, стан персоналу і хороший клімат залишаються непоміченими.

\section{Список бібліографічного опису}

1. Анцупов А.Я., Баклановський С.В. Конфліктологія в схемах та коментарях: навчальний посібник; 2-ге вид., перераб. Санкт-Петербург: Пітер, 2009. $304 \mathrm{c}$.

2. Біловодська О.А., Кириченко Т.В. Управління конфліктами в системі управління людським потенціалом підприємств. Економіка і суспільство. 2017. No 10.0 C. $177-182$. http://www.economyandsociety.in.ua/journal/10 ukr/33.pdf.

3. Краснова Н.П. Причини конфліктів у діловому спілкуванні Соціальна педагогіка: теорія та практика. 2013. № 1. С. 18-26.

4. Новікова Н. Управління конфліктами в організації: підходи до вирішення та профілактики. Галицький економічний вісник. 2013. № 2. С. 7983. URL : http://nbuv.gov.ua/UJRN/gev_2013_2_14.

5. Сергієнко T.I. Конфлікти в колективі і роль керівника у їх вирішенні. Гуманітарний вісник Запорізької державної інженерної академії. 2012. Вип. 48. C. 236-242. URL: http://nbuv.gov.ua/UJRN/znpgvzdia_2012_48_27.

6. Сочинська-Сибірцева I.M. Креативні технології управління конфліктними ситуаціями на вітчизняних підприємствах. Бізнес Інформ. 2012. No 10. C. 271-275. 
Економічні науки: збірник наукових праць Луцького національного технічного університету. Серія "Регіональна економіка". Випуск 18 (71). Редкол.: відп. ред. д.е.н., професор Л.Л. Ковальська. Луцьк: ІВВ Луцького НТУ, 2021. 278 с.

7. Алексєєв О.А. Специфіка вирішення конфліктів у організації // Збірники конференцій НДЦ Соціосфера [Електронний ресурс].- 2013.- Режим доступу: http://elibrary.ru

8. Batool, H \& Riaz, S. Managing the conflict // A situational analysis of Organization in UAE. -Ulsan, 2013. - P.193-199.

\section{References}

1. Antsupov A.Y., Baklanovsky SV Conflictology in schemes and comments: textbook; 2nd ed., Reworked. Saint Petersburg: Peter, 2009. 304 c. [In Russsian]

2. Bilovodskaya OA, Kirichenko TV Conflict management in the system of human resources management of enterprises. Economy and society. 2017. № 10. S. 177-182. URL: http://www.economyandsociety.in.ua/journal/10_ukr/33.pdf. [in Ukrainian]

3. Krasnova NP Causes of conflicts in business communication Social pedagogy: theory and practice. 2013. N 1. S. 18-26. [in Ukrainian]

4. Novikova N. Conflict management in the organization: approaches to resolution and prevention. Galician Economic Bulletin. 2013. № 2. S. 79-83. URL: http://nbuv.gov.ua/UJRN/gev_2013_2_14. [in Ukrainian]

5. Sergienko TI Conflicts in the team and the role of the leader in their resolution. Humanitarian Bulletin of the Zaporizhia State Engineering Academy. 2012. Vip. 48. S. 236-242. URL: http://nbuv.gov.ua/UJRN/znpgvzdia_2012_48_27. [in Ukrainian]

6. Sochinskaya-Sibirtseva IM Creative technologies of conflict management at domestic enterprises. Business Inform. 2012. № 10. S. 271-275. [in Ukrainian]

7. Alekseev OA Specifics of conflict resolution in the organization // Proceedings of conferences NDC Sociosphere [Electronic resource] .- 2013.- Access mode: http://elibrary.ru [In Russsian]

8. Batool, H \& Riaz, S. Managing the conflict // A situational analysis of Organization in UAE. -Ulsan, 2013. - P.193-199. [In Russsian]

DOI: $\underline{\text { https://doi.org/10.36910/2707-6296-2021-18(71)-12 }}$ 